\title{
Commentary
}

\section{Advances in Molecular Hematopathology}

\section{T-Cell Receptor $\gamma$ and bcl-2 Genes}

\author{
Timothy C. Greiner \\ From the University of Nebraska Medical Center, \\ Omaha, Nebraska
}

The two articles by Signoretti et $\mathrm{al}^{1}$ and Bohling et $\mathrm{al}^{2}$ published in this issue of the Journal demonstrate ongoing advances in amplifying T-cell receptor $\gamma$ gene rearrangements (TCR $\gamma \mathrm{GR}$ ) and the translocation of the major breakpoint region of bcl-2 with the immunoglobulin heavy chain gene $(\mathrm{MBR} / \mathrm{JH})$. Both use variations in polymerase chain reaction $(P C R)$ technology. During the first few years' use of PCR in these two genes, analysis of PCR products occurred in standard agarose and polyacrylamide gels. There have been many technical advances since the 1988 description of manual PCR to detect $\mathrm{MBR} / \mathrm{JH}$ rearrangements by Stetler-Stevenson et al. ${ }^{3} \mathrm{Re}-$ cent progress has seen the utilization of fluorescent detection and methods of separating gene rearrangements focused on the differences in DNA sequences of the rearrangements. Three key methods are single-strand conformation polymorphism (SSCP) analysis, ${ }^{4}$ denaturing gradient gel electrophoresis (DGGE), ${ }^{5}$ and temperature gradient gel electrophoresis (TGGE). ${ }^{6}$ Pathologists interested in understanding the basics of DNA sequence separation technologies should read these three articles.

\section{Principles of Analyzing T-cell Receptor $\gamma$ Gene Rearrangements}

One important feature facilitating the amplification of the T-cell receptor $\gamma(\mathrm{TCR} \gamma)$ gene is the limited number of variable region and joining region gene segments that have been described in tumors. These include four families of variable segments, $\vee \gamma 1-8$ (1-8 are closely related in sequence), $V \gamma 9, V \gamma 10$, and $V \gamma 11$, with three groups of joining segments, J $\gamma 1-2, J \gamma P$, and $J \gamma P 1-2 .^{7-9}$ The total number of gene segments is much lower than in the T-cell receptor $\beta$ or the immunoglobulin heavy chain genes and there are also no diversity gene segments. ${ }^{7-9}$ Therefore, it is easy for molecular pathologists to design primers to cover rearrangements of all of the variable region and joining region segments of the TCR $\gamma$ gene. Each of these families or groups of segments requires a unique primer because there is insufficient homology to use just one consensus primer for the variable region and one primer for the joining region genes.

A review of the literature reveals that there are two main groups of protocols: those which detail the amplification of all gene segments and those which amplify only the most common gene segments used in TCR $\gamma \mathrm{GR}$. The most frequently used variable region and joining region segments in peripheral T cell lymphomas are the Group I variable region $(\mathrm{V} \gamma 1-8)$ at $80 \%$ and the $\mathrm{J} \gamma 1 / \mathrm{J} \gamma 2$ group at $60 \% .^{9}$ Thus, common primers can detect approximately $60-80 \%$ of TCR $\gamma$ GR according to the frequency of TCR gene segments used as described by in Theodorou et al. ${ }^{9} \mathrm{~V} \gamma 9, \mathrm{~V} \gamma 10$, and $\mathrm{V} \gamma 11$ are used in decreasing order, and $J y P$ and $J y P 1 / J y P 2$ are used in less than $20 \%$ of TCR $\gamma$ GR. ${ }^{9}$ The detection frequency of TCR $\gamma$ GR with common primers in patient series tends to be higher than this due to the natural tendency to build a collection from positive index cases. It is also higher because biallelic rearrangements usually consist of one rearrangement composed of the commonly used segments and another composed of one of the infrequently used gene segments. Protocols using only a limited number of primers will fail to detect the TCR $\gamma \mathrm{GR}$ with the infrequently used genes. To test a protocol for detecting rearrangements with $\mathrm{J} \gamma \mathrm{P} 1 / 2$, try amplifying DNA from MOLT4 cells.

In rearrangements of the immunoglobulin gene, maximum detection capabilities with Framework III primers are limited to about $80 \%$ due to a combination of mutations at primer sites and the presence of unknown gene segments. Unlike the immunoglobulin gene, we can expect to detect $90-100 \%$ of Southern blot-confirmed TCR $\gamma$ GR when primers to all TCR $\gamma$ gene segments are used. $^{10}$ Therefore, I think pathologists are obligated to use all of the known TCR $\gamma$ genetic information in designing protocols for their laboratory, regardless of whether SSCP, DGGE, TGGE, sequencing gels, heteroduplex, or high density polyacrylamide gels are used. To do less

Accepted for publication November 16, 1998.

Address reprint requests to Timothy Greiner, M.D., Associate Professor, University of Nebraska Medical Center, 983135 Nebraska Medical Center, Omaha, NE 68198-3135. E-mail: tgreiner@mail.unmc.edu. 
than that would, I believe, unnecessarily risk missing a TCR $\gamma \mathrm{GR}$ and may affect patient care.

The use of precast gels in thermally controlled SSCP (Signoretti et $\mathrm{al}^{1}$ in this issue) to analyze T-cell receptor $\gamma$ gene rearrangements is a good addition to recent descriptions of SSCP in various T-cell receptor gene families including $\alpha, \beta$, and $\gamma$ genes. Certainly the use of the precast gels, as also described by Kaul et $\mathrm{al}^{11}$ using a PhastSystem (Pharmacia, Uppsala, Sweden), may be faster than pouring gels for either DGGE or SSCP systems. The goal of controlling temperature during gel electrophoresis is fundamentally important in any method for separating DNA by sequence to obtain high resolution of the DNA bands, as in SSCP. The use of SYBR Green II (Molecular Probes, Eugene, OR) appears to be a useful alternative to silver staining of single-stranded DNA in SSCP.

\section{Alternative Gel Systems for TCRyGR}

Many methods have been described, ranging from early agarose gel-based electrophoresis, which separates DNA by length, to a variety of systems that separate DNA by sequences as well as length. A highly robust analytical electrophoresis system is desirable. The minimum standard is high density polyacrylamide gel electrophoresis to obtain sufficient discrimination between the amplicon products, which do not vary greatly in length with TCR $\gamma$ due to the lack of a diversity region and limited insertions at the junction or $\mathrm{N}$ region. Electrophoresis assays based on DNA sequence separation are more robust in separating DNA, especially biallelic TCR $\gamma \mathrm{GR}$ of the same length. ${ }^{10}$ These are also useful in establishing with certainty that residual disease of a clonal neoplasm is present, based on a comigration in the gel of the rearranged band. The performance of sequence separation systems in mutation detection are nearly equivalent, yet remain dependent on specific DNA sequence and institutional expertise. Separation of TCR $\gamma$ GRs in DGGE is maximized by the incorporation of a guanine-cytosine (GC) clamp in the PCR product. ${ }^{10,12}$ Representative reports suggest the use of TGGE in TCR $\gamma \mathrm{GR}^{13-15}$ appears equivalent to results seen in DGGE and SSCP. Newer methods involving fluorescent labeling of TCR $\beta^{16}$ and $\gamma^{17,18}$ GR PCR products with, eg, the ABI Gene Scan system (Applied Biosystems, Foster City, CA) a type of fluorescent SSCP, have been described; however, the instrumentation is very expensive. I and others have observed that this system discriminates very well by length ${ }^{16-18}$ and it has the added potential advantage of calculating comparisons between peak heights. This may prove useful in resolving a difficulty in all systems: discriminating oligoclonal expansions from neoplastic clones.

\section{Fluorescent Detection System}

The article by Bohling et $\mathrm{al}^{2}$ describes a new way to detect PCR products that may lend itself to real time analyses, an elusive goal of several companies over the last five years. A recent advance in analyzing fluorescent- labeled MBR/JH products included the application of the $\mathrm{ABI}$ Gene Scan (ABI, Molecular Probes) in a standard polyacrylamide gel. ${ }^{19}$ This system still represented a post-PCR electrophoresis. The fluorescent detection with SYBR Green I in the glass tube as described by Bohling et $\mathrm{al}^{2}{ }^{2}$ however, uses properties of change in fluorescence that occurs with DNA strand association/disassociation coupled with measuring the temperature at which the DNA denatures. Such innovations are to be encouraged as laboratories continue changing from standard analyses of PCR products in labor-intensive agarose and polyacrylamide gels.

Background references that readers would find useful in understanding the technology described in this manuscript include the schematic article on the LightCycler instrument by Wittwer et $\mathrm{al}^{20}$ and the principles of measuring DNA melting curves described by Ririe et al in 1997. ${ }^{21}$ These two articles break new ground in showing a potential application combining an understanding of DNA melting characteristics and fluorescent detection technology.

The application of this technology appears best suited for the detection of abnormal events such as neoplastic translocations, infectious disease agents, or mutations that have a significant difference in melting temperature. Members of Wittwer's group have previously illustrated a possible use in infectious diseases by amplifying the hepatitis B surface antigen ${ }^{21}$ with the LightCycler and others have demonstrated the capability in identifying Leptospira species. ${ }^{22}$ Most recently a LightCycler protocol has been published to identify a hemachromatosis gene mutation using yet another advance by incorporating the use of peptide nucleic acid probes ${ }^{23}$ during PCR. Since amplified polyclonal $\mathrm{JH}$ or TCR $\gamma$ rearrangements would affect fluorescent changes, it is not likely that this technique could be adapted easily in these areas.

The possibilities of incorporating this detection technology may be limited by the practice of confirming the identity of PCR products by hybridization techniques, such as dot blots or ELISA-based technology, along with the trend of directly sequencing PCR products. One concern about relying on DNA melting profiles to identify a specific product is that another DNA sequence may have the same melting temperature. A thorough understanding of DNA melting technology should, however, allow for the development of specific applications, such as the $\mathrm{MBR} / \mathrm{JH} \mathrm{t}(14 ; 18)$ translocation, provided there are no known nonspecific products such as cross-reaction with Epstein-Barr virus. ${ }^{24}$

One slight drawback with previous generations of rapid cyclers, which we have experienced in our laboratory, is difficulty in loading and handling the capillary tubes. The innovators have attempted to address this with a new plastic loading unit for the capillary tubes that may make it more user friendly. ${ }^{2}$

\section{The Problem of Sporadic bcl-2 MBR/JH Rearrangements}

$\mathrm{MBR} / \mathrm{JH}$ rearrangements have been described in individuals with no disease or with reactive hyperplasia. ${ }^{25,26}$ The 
best way to identify sporadic bcl-2 translocations is by duplicate tube analysis and they can usually be avoided by using a nonnested protocol. ${ }^{27}$ If the suspect translocation is not repeatable in multiple tube assays it is best regarded as sporadic when one is considering a primary diagnosis. In follow-up biopsy specimens in an established patient the best course of action is to use comparative analysis for comigration of $\mathrm{MBR} / \mathrm{JH}$ in the two biopsy specimens.

\section{Future of Molecular Hematopathology}

Advances during the past decade have resulted in numerous protocols for detecting gene rearrangements and translocations in lymphoma and leukemia by PCR. Therefore, gel systems and primers vary from institution to institution, making comparisons difficult. The Association for Molecular Pathology and the National Committee on Clinical Laboratory Standards are making ongoing efforts to determine whether consensus protocols can be devised. 28

\section{References}

1. Signoretti S, Murphy M, Cangi MG, Puddu P, Kadin ME, Loda M: Detection of clonal T-cell receptor $\gamma$ gene rearrangements in paraffin embedded tissue by PCR and non-radioactive SSCP analysis. Am J Pathol 1999, 154:67-75

2. Bohling SB, King TC, Wittwer CT, Elenitoba-Johnson KSJ: Rapid simultaneous amplification and detection of the MBR/JH chromosomal translocation by fluorescence melting curve analysis. Am J Pathol 1999, 154:97-103

3. Stetler-Stevenson M, Raffeld M, Cohen P, Cossman J: Detection of occult follicular lymphoma by specific DNA amplification. Blood 1988 , 72:1822-1825

4. Orita M, Iwahana H, Kanazawa $H$, Hayashi K, Sekiya $T$ : Detection of polymorphisms of human DNA by gel electrophoresis as singlestranded conformation polymorphisms. Proc Natl Acad Sci USA 1989, 86:2766-2770

5. Fischer SG, Lerman LS: DNA fragments differing by single base-pair substitutions are separated in denaturing gradient gels: correspondence with melting theory. Proc Natl Acad Sci USA 1983, 80:15791583

6. Ke SH, Wartell RM: Influence of nearest neighbor sequence on the stability of base pair mismatches in long DNA: determination by temperature-gradient gel electrophoresis. Nucleic Acids Res 1993, 21:5137-5143

7. LeFranc MP, Forster A, Baer R, Stinson MA, Rabbitts TH: New subgroups in the human $T$ cell rearranging $\gamma$ genes: nine germline variable genes belonging to two subgroups. Cell 1986, 45:237-246

8. Huck S, LeFranc MP: Rearrangements to the JP1, JP and JP2 segments in the human T-cell rearranging $\gamma$ gene (TRG $\gamma$ ) locus. FEBS Lett 1987, 224:291-296

9. Theodorou I, Raphaël M, Bigorgne C, Fourcade C, Lahet C, Cochet G, LeFranc MP, Gaulard P, Farcet JP: Recombination pattern of the TCR $\gamma$ locus in human peripheral T-cell lymphomas. J Pathol 1994, 174:233-242

10. Greiner TC, Raffeld M, Lutz C, Dick F, Jaffe ES: Analysis of T cell receptor- $\gamma$ gene rearrangements by denaturing gradient gel electrophoresis of GC-clamped polymerase chain reaction products: correlation with tumor-specific sequences. Am J Pathol 1995, 146:46-55

11. Kaul K, Petrick M, Herz B, Cheng TCP: Detection of clonal rearrange- ment of the T-cell receptor $\gamma$ gene by polymerase chain reaction and single-strand conformation polymorphism (PCR-SSCP). Mol Diagn 1996, 1:131-137

12. Theodorou I, Delfau-Larue MH, Bigorgne C, Lahet C, Cochet G, Bagot M, Wechster J, Farcet JP: Cutaneous T-cell infiltrates: analysis of T-cell receptor $\gamma$ gene rearrangements by polymerase chain reaction and denaturing gradient gel electrophoresis. Blood 1995, 86: 305-310

13. Kneba M, Bolz I, Linke B, Bertram J, Rothaupt D, Hiddemann W: Characterizations of clone-specific rearrangement T-cell receptor $\gamma$-chain genes in lymphomas and leukemias by the polymerase chain reaction and DNA sequencing. Blood 1994, 84:574-581

14. Menke MA, Tiemann M, Vogelsang D, Boie C, Parwaresch R: Temperature gradient gel electrophoresis for analysis of a polymerase chain reaction-based diagnostic clonality assay in the early stages of cutaneous T-cell lymphomas. Electrophoresis 1995, 16:733-738

15. Scheller U, Muche JM, Sterry W, Lukowsky A: Detection of clonal T cells in cutaneous $T$ cell lymphoma by polymerase chain reaction: comparison of mutation detection enhancement-polyacrylamide gel electrophoresis, temperature gradient gel electrophoresis and fragment analysis of sequencing gels. Electrophoresis 1998, 19:653-658

16. Kneba M, Bolz I, Linke B, Hiddemann W: Analysis of rearranged t-cell receptor $\beta$-chain genes by polymerase chain reaction (PCR) DNA sequencing and automated high resolution PCR fragment analysis. Blood 1995, 86:3930-3937

17. Greiner TC: Analysis of TCR $\gamma$ gene rearrangement by two methods: Denaturing gradient gel electrophoresis and laser-scanning of fluorescent-labelled products. The Antigen T Cell Receptor: Selected Protocols and Applications. Edited by JR Oksenberg. Austin, TX, R.G. Landes Company, 1997, pp 407-431

18. Simon M, Kind P, Kaudewitz P, Krokowski M, Graf A, Prinz J, Puchta U, Medeiros LJ, Sander CA: Automated high-resolution polymerase chain reaction fragment analysis: a method for detecting T-cell receptor $\gamma$-chain gene rearrangements in lymphoproliferative diseases. Am J Pathol 1998, 152:29-33

19. Luthra R, McBride JA, Hai S, Cabanillas F, Pugh WC: The application of fluorescence-based PCR and PCR-SSCP to monitor the clonal relationship of cells bearing the $t(14 ; 18)(q 32 ; q 21)$ in sequential biopsy specimens from patients with follicle center cell lymphoma. Diagn Mol Pathol 1997, 6:71-77

20. Wittwer CT, Ririe KM, Andrew RV, David DA, Gundry RA, Balis UJ: The LightCycler ${ }^{\mathrm{TM}}$ : A microvolume multisample fluorometer with rapid temperature control. Biotechniques 1997, 22:176-181

21. Ririe KM, Rasmussen RP, Wittwer CT: Product differentiation by analysis of DNA melting curves during the polymerase chain reaction. Anal Biochem 1997, 245:154-160

22. Woo TH, Patel BK, Smythe LD, Symonds ML, Norris MA, Weyant RS, Dohnt MF: Identification of Leptospira inadai by continuous monitoring of fluorescence during rapid cycle PCR. Syst Appl Microbiol 1998, 21:89-96

23. Kyger EM, Krevolin MD, Powell MJ: Detection of the hereditary hemochromatosis gene mutation by real-time fluorescence polymerase chain reaction and peptide nucleic acid clamping. Anal Biochem 1998, 260:142-148

24. Segal GH, Scott M, Jorgensen T, Braylan RC: Primers frequently used for detecting the $t(14 ; 18)$ major breakpoint also amplify Epstein-Barr viral DNA. Diagn Mol Pathol 1994, 3:15-21

25. Limpens J, de Jong D, van Krieken JH, Price CG, Young DB, van Ommen G, Kluin PM: Bcl-2/JH rearrangements in benign lymphoid tissues with follicular hyperplasia. Oncogene 1991, 6:2271-2276

26. Aster JC, Kobayashi Y, Shiota M, Mori S, Sklar J: Detection of the $t(14 ; 18)$ at similar frequencies in hyperplastic lymphoid tissues from American and Japanese patients. Am J Pathol 1992, 141:291-299

27. Segal GH, Scott M, Jorgensen T, Braylan RC: Standard polymerase chain reaction analysis does not detect $\mathrm{t}(14 ; 18)$ in reactive lymphoid hyperplasia. Arch Pathol Lab Med 1994, 118:790-791

28. O'Leary TJ, Stetler-Stevenson M: Diagnosis of $t(14 ; 18)$ by polymerase chain reaction: The natural evolution of a laboratory test. Arch Pathol Lab Med 1994, 118:789-790 